Taxation

\section{UK budget hits research councils}

BRITISH universities and research councils are still trying to count the likely cost of changed arrangements for the taxation of building works that came into effect at the beginning of June.

Under new regulations announced by the Chancellor of the Exchequer, Mr Nigel Lawson, in his budget speech in April, the cost of extensions or alterations to existing buildings (but not the cost of new buildings) is subject to Value Added Tax (VAT), now set at 15 per cent. On first estimates, the cost to the research councils could amount to $\mathbf{f l}$ million in the current financial year, while universities face additional bills of between $£ 3$ million and $£ 5$ million all told.

Of the research councils, the Natural Environment Research Council (NERC) is much the worst affected. The council is at present negotiating with HM Customs and Excise over how exactly the new rules should be interpreted - it has already been awarded one favourable decision - but says that the VAT changes will cost it $£ 100,000$ even if other decisions all go in its favour; if they do not, the cost will be nearer five times as much.

NERC's chairman, Sir Hermann Bondi, has written to Mr Peter Brooke, UnderSecretary of State for Higher Education, asking for an assurance that the new VAT charges will constitute an admissible claim for supplementary grant. But Mr Brooke has not so far given any such assurance, although it is understood that discussions are being held with the Treasury over ways to help research councils. The Treasury, however, is unlikely to want to establish the precedent that public bodies can be excused VAT.

The greater proportion of NERC's VAT problems arise at one site, the new headquarters of the British Geological Survey at Keyworth in Nottinghamshire. The buildings are mostly conversions from their previous use as a college of education, and the Keyworth site alone could cost NERC up to $£ 380,000$ in VAT payments. In this event it is clear that building works would have to be delayed.

As if the VAT problems were not enough, the British Geological Survey also has serious problems with the landlord of its old London base in South Kensington. The Property Services Agency of the Department of the Environment, which administers and maintains the building, has presented NERC with a bill for $£ 280,000$ for back-payment on maintenance work, and estimates that maintenance will in future cost $£ 350,000$ a year. Since 1977 , NERC has been paying just $£ 98,000$ per year for maintenance, and although some back-dated increase was expected, the amount came as a shock. In addition to the maintenance charges, rental on the building has been increased from $£ 350,000$ to $£ 500,000$ per year. NERC is still withholding the maintenance backpayment and the rent increase in the hope of being able to negotiate a compromise. But the Property Services Agency appears determined to hold out for what it describes as "reasonable and realistic" charges. The building is shortly to be transferred to the British Museum (Natural History).

In comparison with these financial headaches, the problems of the other research councils seem mild. The Science and Engineering Research Council says the VAT changes are likely this year to cost it $£ 115,000$, while the Agricultural and Food Research Council and the Medical Research Council each estimate around $£ 200,000$. Neither holds out much hope of any special allowance to recoup the cost.

\section{Soviet refusnik}

Dr Ephraim Katchalsky-Katzir, the Israeli biochemist, who was one of the leading speakers at last week's conference of the Federation of European Biochemical Societies, was last weekend unable to carry through his post-conference plans for a meeting with Jewish activists in Leningrad.

The meeting was convened by Yakov Gorodetskii, one of the activists of the unofficial Leningrad Jewish Cultural Seminar. More than 80 refusniks (Jews deprived of their jobs after applying to emigrate to Israel and then refused a visa) arrived at the appointed place, but Dr Katxir was unable to be present, being confined to his hotel room by members of the security police.

Gorodetskii and his fellow activists in Leningrad had just issued an appeal to the British Foreign Minister, Sir Geoffrey Howe, to raise the issue of Jewish emigration during his talks in Moscow with his Soviet opposite number, Mr Andrei Gromyko. This may well have focused the attention of the authorities on the group.

The current Soviet stance on emigration was spelled out in a TASS dispatch on Saturday concerning the Latvian Jew, Zakhar Zunshein, sentenced last week to three years' imprisonment for "anti-Soviet activities"'. Mr Zunshein's five-year campaign for a visa was described as "insulting" to the Soviet Union, and he himself was described as "inhuman", since he was ready to "abandon his parents" by going to Israel, thereby, according to TASS, contravening the Helsinki accords.

From the Soviet point of view, the Katzir incident comes as a sad postscript to a conference that had been given priority treatment. The publicity build-up in the Soviet media was considerable, including a half page article in Pravda by Academician Yurii Ovchinnikov.
Universities have been more vocal in their opposition to VAT changes. The University Grants Committee, among others, has been petitioning the Treasury for some relief for universities. Some older universities will escape the new VAT if their proposed alterations are to buildings listed by the Department of the Environment as being of special architectural interest, but there is nevertheless anger than universities which tightened their belts and delayed building programmes during the major squeeze on universities three years ago are now being "penalized for good financial management", in the words of Sir Alwyn Williams, vice-chancellor of the University of Glasgow.

Tim Beardsley

\section{European Community}

\section{No decisions on research}

\section{Luxembourg}

THE meeting of the research ministers of the European Community on 29 June fell a victim to the European timetable. It was too soon after the economic summit at Fountainebleau, which resolved the longstanding British budget problem, to tell how much cash was available for the ambitious programmes awaiting decision, and too soon also to be able to define priorities.

The programmes concerned include the stimulation programme, designed to help scientists to take advantage of all possible professional exchanges, whether multidisciplinary, multicultural or multinational; the BRITE programme (Basic Research in Technology for Europe), designed to help older industries to become familiar with innovative technology, and biotechnology, nonnuclear energy, radiation protection, reactor safety and fusion.

At the end of the meeting, Vicomte Etienne Davignon, vice-president of the European Commission, said that there will probably be another research council meeting this month when ministers have had time for reflection. Officials of the Science, Research and Development directorate-general, putting a brave face on things, said that at least the past few years have seen almost unanimous support for the scientific content of new programmes, and they have been better able to manage their own budget.

Earlier in the week, however, the Communities' environment ministers had been able to decide that unleaded petrol will come a little earlier than expected. On 24 June, they agreed to the introduction of petrol without the anti-knock additive before 1989.

The British Government has already announced a planned reduction of the level of lead in petrol from 0.4 to $0.14 \mathrm{~g}$ per litre by the end of next year. 